Article

\title{
Why Is the Construction Industry Killing More Workers Than the Offshore Petroleum Industry in Occupational Accidents?
}

\author{
Kinga Wasilkiewicz Edwin ${ }^{1, *} \mathbb{C}$, Marie Nilsen ${ }^{1,2}$ and Eirik Albrechtsen ${ }^{1}$ \\ 1 Department of Industrial Economics and Technology Management, Norwegian University of Science and \\ Technology, 7491 Trondheim, Norway; marie.nilsen@ntnu.no (M.N.); eirik.albrechtsen@ntnu.no (E.A.) \\ 2 Studio Apertura, NTNU Social Research, 7491 Trondheim, Norway \\ * Correspondence: kinga.edwin@ntnu.no
}

check for updates

Citation: Edwin, K.W.; Nilsen, M.; Albrechtsen, E. Why Is the Construction Industry Killing More Workers Than the Offshore Petroleum Industry in Occupational Accidents? Sustainability 2021, 13, 7592. https:// doi.org/10.3390/su13147592

Academic Editor: Antonio Caggiano

Received: 22 May 2021

Accepted: 1 July 2021

Published: 7 July 2021

Publisher's Note: MDPI stays neutral with regard to jurisdictional claims in published maps and institutional affiliations.

Copyright: (c) 2021 by the authors. Licensee MDPI, Basel, Switzerland. This article is an open access article distributed under the terms and conditions of the Creative Commons Attribution (CC BY) license (https:// creativecommons.org/licenses/by/ $4.0 /)$.

\begin{abstract}
In Norway, the fatal accident frequency per year is discernibly higher in the construction industry than in the petroleum industry. To probe the difference between the occupational safety levels in the two industries in Norway, semi-structured interviews with regulators, employer and employee organisations, company management, and safety personnel were conducted. This qualitative approach, together with factual industry information, offer invaluable insight on various elements influencing occupational safety. Rasmussen's socio-technical model is used to sort the information and compare framework conditions, characteristics and aspects of the two industries influencing safety. Though the construction industry's safety level has improved over the years, the results indicate that the petroleum industry's safety level is still considered superior to its counterpart. The interviews point to major accidents and regulations as important for safety development in the petroleum industry. Thorough planning of operations, stricter rules, more standardised procedures and requirements, and fewer actors in the petroleum industry are also highlighted. The results of this study further reveal that safety in the construction industry has benefitted from safety developments in the petroleum industry. There is potential for more learning across the industries, in particular from petroleum to construction with regard to standardisation, barrier-thinking, and knowledge-sharing.
\end{abstract}

Keywords: framework conditions; construction; petroleum; fatalities; occupational safety; Norway

\section{Introduction}

Between 2000 and 2020, 160 occupational fatal accidents occurred in the Norwegian construction industry, against only eight in the Norwegian petroleum industry [1]. However, looking back at the first two decades of operation of the offshore petroleum industry in Norway; i.e., the 1960s and 1970s, statistics show that the injury and fatality numbers were much higher, decreasing significantly over the years $[2,3]$. In the construction industry, injury and fatality numbers also have decreased greatly since the 1960s and 1970s, but not nearly as much as in the petroleum industry (see Figures 1 and 2) $[1,2,4,5]$. The two industries operate in different environments and with different risks; nevertheless, a fatality is as unwanted in one industry as in the other. These developments, the fact that the petroleum industry is a locomotive for safety in Norway, and the two industries often being compared without a structured or scientific approach are motives for a comparison of the occupational safety between the two.

Figure 1 shows the occurrence of fatal accidents between 1970 and 2020 for both the industries, and the average number of fatalities over a 10 -year period $[1,4]$. The petroleum industry has only had a few fatal accidents since the 1990s, as compared to the construction industry, in which the number of fatalities is still high. Figure 2 shows the yearly fatality rate per 100 million working hours in the two industries with 10-year averages [1,5,6]. Although there are uncertainties related to the numbers, such as reporting quality and coincidence regarding the outcomes of accidents, they give a pointer to the safety levels in the two industries. 


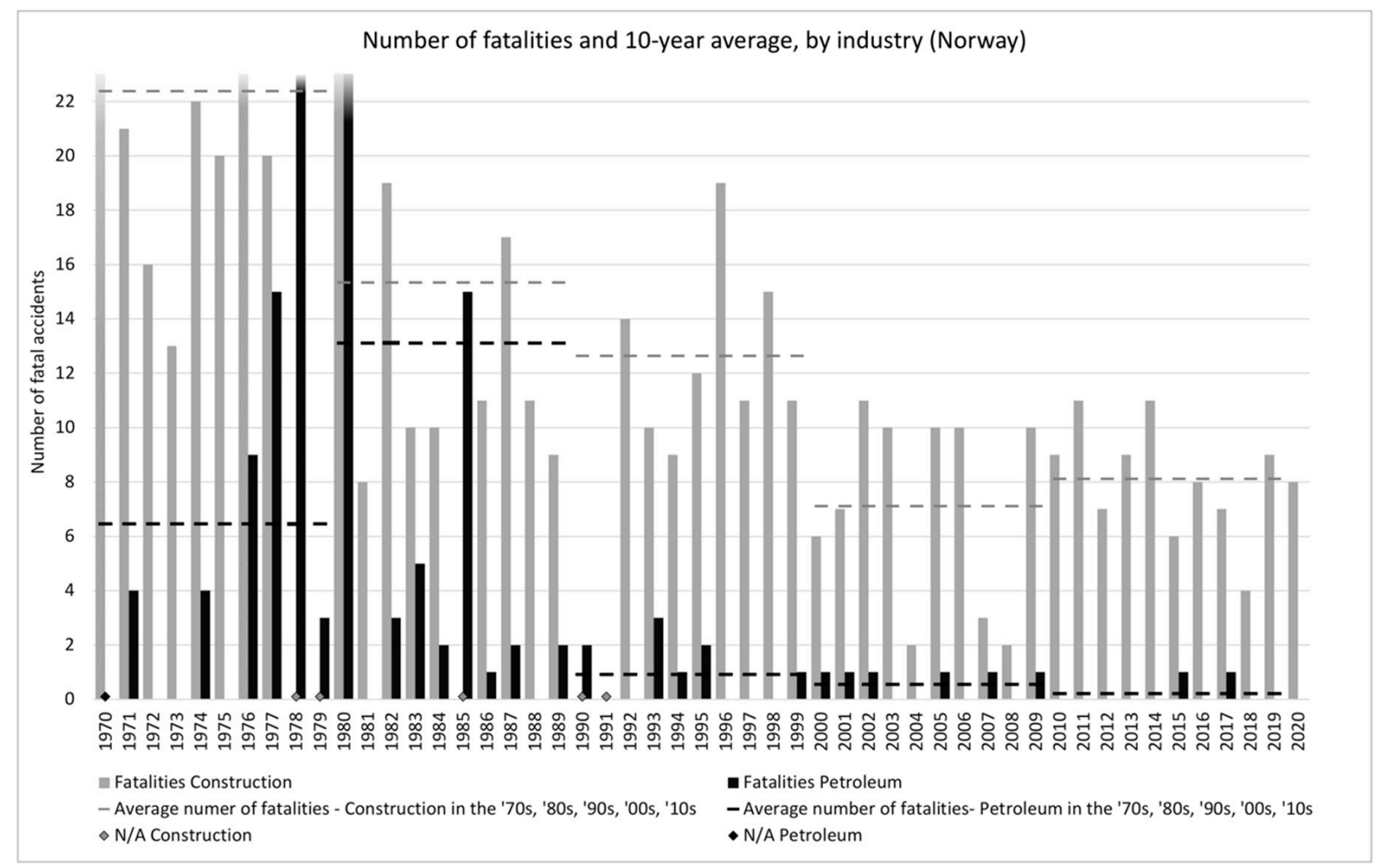

Figure 1. Number of fatalities in the Norwegian construction and petroleum industries and 10-year averages for 1970-2020 (excluding helicopter accidents) based on total hours worked for employees and self-employed in construction and oil and gas extraction, excluding services (from Statistics Norway (SSB)) [4-6]. The rhombus points indicate missing values, N/A—not available (1970 for petroleum, and 1978, 1979, 1985, 1990, and 1991 for construction). The values for 1970, 1976, and 1980 for construction, and 1978 and 1980 for petroleum, are beyond the range of the graph.

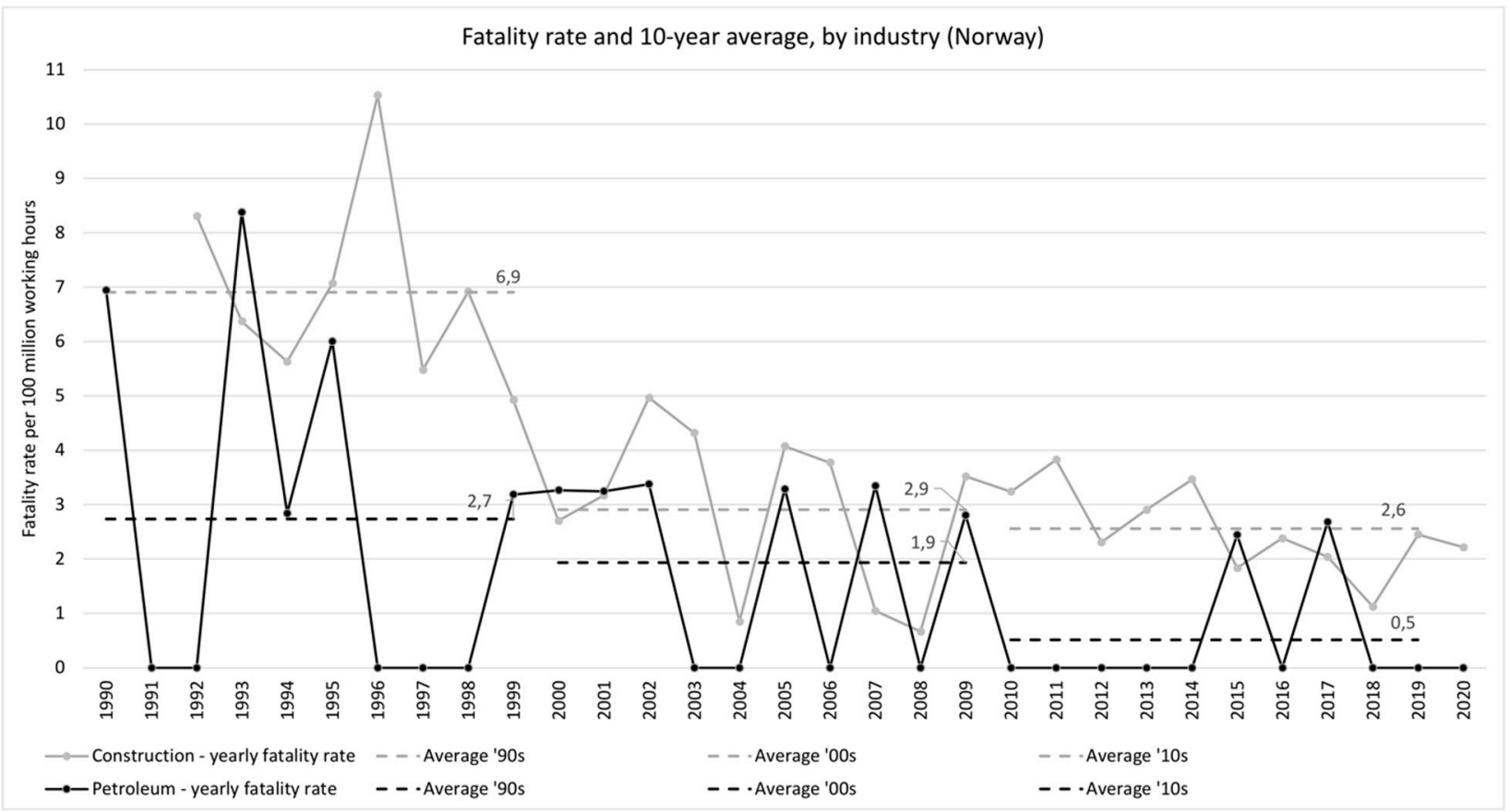

Figure 2. Fatality rates per 100 million working hours for the Norwegian construction and petroleum industries for 1990-2020 (excluding helicopter accidents). Values for 1990 and 1991 for the construction industry are missing. The graph is based on fatality numbers and working hours from SSB $[1,5,6]$. 
Many of the occupational accidents that occur in the two industries are of similar types. Among the most frequent accident types leading to injuries in the Norwegian construction industry are fall accidents, contact with a falling object, and contact with moving machinery parts [7], of which, being struck by a falling object, being in/on a vehicle that has lost control, and falls from height led to most fatalities between 2011 and 2017 [8]. Since 2000, fatalities in offshore petroleum have been related to a person being struck by an object, falls from height, and a facility being struck by a wave [9-13]. Data from the UK show that between 2012 and 2018, offshore accidents related to slips, trips, and falls (from same levels and height) and being struck by moving object accounted for more than half of all reported injuries with major or fatal severity [14]. In Norway, the Petroleum Safety Authority Norway (PSA) focuses largely on accidents related to crane and lifting operations and on falling objects through their defined situations of hazards and accidents [15].

An analysis of construction accidents in Norway in 2019 points to actions and behaviour, operative management, and risk management as the most frequent and important contributing factors to the accidents [16]. Barrier-control approaches similar to those in offshore petroleum, implementing multiple physical barriers to control a specific hazard, is identified as a potential approach for accident prevention in construction activities [7]. In petroleum, failures in operational barriers contribute to a large number of accidents [15]. In addition, management styles and trust in management have been found to be important for personal injuries in the petroleum industry [17]. A focus on factors related to work systems, project management, and higher management, as well as framework conditions, can give further insight into root causes influencing accidents and safety [18].

Though a direct comparison of fatality numbers between the two industries can be misleading, similarities in the nature of occupational accidents, and differences in improvement over the years between the industries, are interesting to note. The objective of this study is to explore how the petroleum industry has manged to improve on safety, and what it can mean for the construction industry. Understanding how different factors have affected and currently affect safety in each of the industries can help to identify what limits construction from improving safety and operating sustainably without harm to people. The United Nations emphasises the importance of promoting safe and secure working environments in their sustainability goals (No. 8) [19]. Furthermore, accidents not only result in human, environmental, and material losses, but they can also influence progress and the economy [20]. A good safety performance also is likely to contribute to success in other operational aspects [21], and thus lead to sustainable value creation.

The purpose of this paper is to explain factors behind the differences in the number of occupational fatalities of the two identified Norwegian industries by answering the following two research questions: (1) What effects do industry characteristics and framework conditions have on the level of safety in the two industries? (2) What learning points from the petroleum industry can contribute to improvement of safety in the construction industry?

Characteristics, framework conditions, and safety developments of the two industries were explored through qualitative interviews, supporting literature, and reports. A total of 36 interviewees distributed equally between the Norwegian offshore petroleum industry and the Norwegian construction industry provided their valuable inputs for this research. Several of the interviewees currently in construction had experience in both industries.

The differences between the two industries were studied using a systems perspective, giving insights on each industry's generic underlying conditions and their influence on safety. Rasmussen's socio-technical model involved in risk management [22] (Figure 3) was applied as a starting point to systematically structure the influences on safety from policymakers down to the sharp end. To the authors' best knowledge, no previous studies have compared the occupational safety of these two industries in a Norwegian context. 


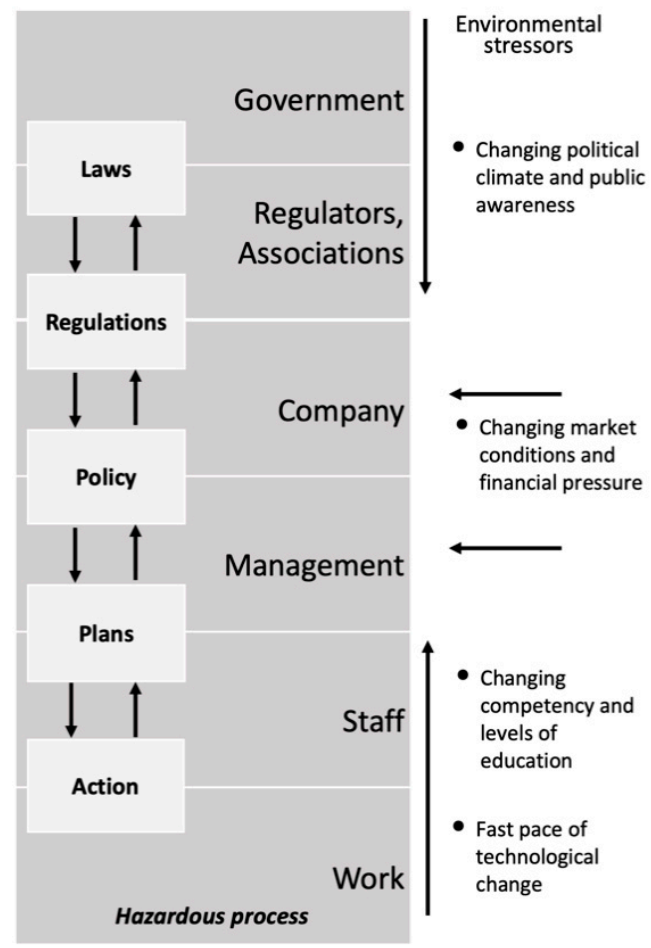

Figure 3. Simplified model of Rasmussen's socio-technical system involved in risk management [22].

\section{Theoretical Framework}

Rasmussen's aim of the model was to demonstrate how levels, disciplines, and factors, both external and internal, can influence and control or trigger accidents in a work process [22]. The model has been frequently cited, and its popularity can be attributed to its generic and holistic perspective, which makes it relevant and applicable for most industries. The simplified version of the model in Figure 3 shows how the different stakeholders are arranged according to their distance from the hazardous process-with government at the highest level and farthest from the hazardous process, and the staff closest to the work process and to the hazard. At the top, society seeks control of hazardous processes through the legal system, while on the next level, the legislation is interpreted and implemented by rules to control activities by regulators, industrial associations, and workers' unions. Next, the regulations are interpreted and implemented in company-specific policies. Within the company, the company policy frames management plans and actions by managers and workers to control hazardous processes. Different environmental stressors are shown to the right in the figure. From a safety perspective, such stressors, also called environmental conditions, can be defined as "conditions that influence the opportunities an organisation, organisational unit, group or an individual has to control the risk of major accidents and working environment risk" [23] (p. 1967). Rasmussen especially had a focus on organisational and managerial aspects in his model [24]. By this, the model shows the importance of a wider approach across disciplines, including feedback loops running upwards in the hierarchy, being a key to ensure that the levels have knowledge about the safety performances at lower levels as input to modifications of control mechanisms. These are factors that contribute to risk management in a dynamic society.

One of the merits of the model is that it identifies the different actors' contribution and links to safety at the sharp end, which makes it suitable as a framework to compare the construction and petroleum industries. Although it is popular, Le Coze [25] has pointed out some weaknesses in the model, such as linear and hierarchical connections between the levels, which in reality do not need to follow the level structure. However, the model adds depth to the comparison by including a wide range of aspects, and gives a visual overview 
of the different elements affecting safety in the two industries. It also places safety in a macro perspective and embraces cross-disciplinary research [24].

\section{Characteristics and Framework Conditions of the Two Norwegian Industries 2.1. Accident Numbers}

The first fatality in the offshore petroleum industry in Norway was reported in 1967, and the largest accident on the Norwegian Continental Shelf (NCS) happened in 1980, when the semi-submersible Alexander Kielland platform, a flotel, capsized and claimed 123 lives [26]. Since 1981, occupational accidents have dominated as a cause of fatalities, rather than major accidents (such as the Kielland accident) [15]. In the industry's early years, the fatal accident rate per 100 million working hours for fixed facilities was around 230, and from the mid-1980s through the 1990s, stabilised at around three [2]. For mobile fatalities, the value was around 100 in the mid-1970s, and fell to 14 in the mid-1980s and remained around that level until 1998, when it started decreasing further [2]. For both types, fatal accident rates, from an average of above 100 per 100 million working hours, greatly improved to 3.3 in the 1990s, and further to 0.5 in the period of 2016-2020 [15].

The petroleum industry has experienced more fatal accidents related to transportation, with one recent example being the Turøy helicopter accident in 2016, which claimed 13 lives. However, in this comparison, transportation accidents were excluded, as the focus was on occupational accidents during work activities with the PSA and the Norwegian Labour Inspection Authority (NLIA) as regulators.

There has also been a reduction in the number of injuries occurring since reporting started in 1978 and 1990 for production and mobile facilities, respectively [2]. The number of personal injuries per million working hours for production facilities decreased from around 30 to 40 in the 1980s to 25 in the 1990s [2], and further to around 7.3 in 2010 and to 5.0 in 2020 [15]. For floating facilities, the number of injuries per million working hours was between 31 and 35 in the 1990s [2], and declined to 5.8 in 2010 and 3.9 in 2020 [15].

For the construction industry, the average number of fatalities per year between 1967 and 1976 was around 25 (ranging from 13 to 43 fatalities per year), which translates to around 11.7 fatalities per 100 million working hours [4-6]. In the years 2000-2019, there were, on average, eight fatalities per year (between two and 11 per year), with around 2.6 fatal accidents per 100 million working hours [1,27]. The reported number of injuries in the period 1967-1977 was, on average, 18.5 per million working hours (around 3500-4500 reports per year) [4,5], whereas the average between 2014 and 2019 was more than halved, to around 7.9 per million working hours (around 2600-2800 reports per year) [27]. The construction industry has seen a great improvement in occupational safety. However, there is still a large scope for improvement.

\subsection{Work Characteristics}

The petroleum and construction industries are different in many ways, including in terms of age, size, and value creation. While the construction industry has nearly always existed, the first production licences on the NCS were given out in the mid-1960s, the first exploration well on the shelf was drilled in 1966, and the first production started in 1971 [28]. The difference in size between the two industries is significant with the construction industry in Norway employing around 10 times more persons than the petroleum industry (based on employees and self-employed, excluding services) - 246,400 and 24,500 persons, respectively, in 2020 [5]. The exposure in terms of worked hours is important to consider when comparing accident statistics of the two industries. Estimated workforce offshore in 2017 was 25,000 employees (including the service and supply industry) [29]. An even more substantial difference is in the number of establishments. In the petroleum industry in 2020, there were 24 operators and 13 companies with production licenses [30], and additionally over 1100 suppliers and sub-contractors supporting tasks such as service and maintenance (but not all offshore) [31]. In the construction industry, most of the almost 69,000 (per 2020) establishments were small, with $91 \%$ having less than 10 employees each. Close to 
two-thirds of all the registered companies were one-person firms, and only around $1 \%$ had more than 50 employees [32].

The construction industry is project-based, and there are many variations within projects that affect daily operations, including project size, company size, contract practices, and private versus public clients. Having a complex project organisation is found to create significant health, safety, and environment (HSE) challenges [33]. When it comes to safety, the petroleum industry is exposed to major accident risks (i.e., accidents killing more than five people) in addition to occupational accident risks, which affects how all activities are carried out. In the construction industry, the risks are closely related to specific work activities and are mainly occupational. In this paper, safety is compared in two different project phases: for construction, it is during building, and for petroleum, mainly during offshore operations.

\subsection{Regulators and Regulations}

Different authorities supervise safety in the two industries, the PSA and the NLIA. These two authorities have very different fields of operations, regulations, and resources. The PSA, in 2020, with 180 employees, was responsible for supervising 80 permanent installations and around 60 mobile units at the NCS, eight major land-based plants, and several subsea installations and petroleum pipelines [34]. The PSA primarily uses dialogue as a means of supervision, although they also make use of other strategies such as notification of order and, in more severe cases, requiring a shutdown of operations until the safety issue is resolved. The PSA's regulatory performance-based approach encourages the adoption of industry standards and best practices [35]. PSA is also responsible for the monitoring program known as the "RNNP" (trends in risk level in the petroleum industry), which is a collaborative effort that results in yearly reports measuring the impact of HSE work in the industry [36].

The NLIA is the supervising authority for all other land-based enterprises in Norway, spanning large international firms to one-person businesses. It is important to highlight that safety-related supervision is just one of the areas of responsibility within NLIA's jurisdiction. The NLIA comprised around 650 employees (580 person-years) in 2020, and in the years 2016-2020, performed on average almost 10,500 inspections yearly of preventive work environments, work health and safety, and good working conditions, of which more than one in three targeted the construction industry [37]. Many of the inspections in the construction industry are unannounced and can result in improvement orders, stoppage of work, or even fines for serious violations [37]. In the period of 2013-2016, the NLIA had a campaign regarding the prevention of injuries and health problems related to work at construction sites [38].

In the 1960s, safety and working-environment regulations in the petroleum industry in Norway were mostly based on existing regulations from other industries and started with "a Wild West Texan approach" [39], with fragmented regulations and responsibilities. Over the years, the petroleum industry has experienced several large-scale accidents that had profound effects on the regulation of safety on the NCS. The Ekofisk Alpha fire and lifeboat accident in 1975 and the Bravo blowout in 1977 were events that paved the way for Norway's Work Environment Act of 1977 [40]. The safety regulations also provided the workers' unions with a strong platform for collective bargaining and the right to stop work when working conditions offshore were deemed unsafe [41]. Another event that had a massive impact on the industry was the Aleksander Kielland accident in 1980 [26]. Following that disaster, the Principles of Internal Control (1981), which required the responsible party to comply with the regulations through systematic and documented HSE work [36], and the Petroleum Act (1985) were introduced [40].

A new regulatory regime and administrative model were established in 1985 [36]. Regulations after this time became risk-based, with performance-based (functional) requirements; clear responsibilities, transparency, and collaboration between actors of major importance in the government-supervised self-regulation regime $[35,36]$. Enforced self- 
regulation in the petroleum industry transferred the responsibilities of managing risks to the companies and required them to develop their own safety-management system or internal control [42]. The Petroleum Act [43] and the Working Environment Act [44] specify, respectively, overall safety requirements and requirements for the working environment. A further five sets of regulations, among them the Framework Regulations [45], provide more detailed requirements for HSE [46]. In 2002, following the government's concern for HSE in the industry [47], the PSA introduced the requirement of having a "sound HSE culture" in the Framework Regulations. This introduction signalled the regulator's desire to explore various ways of looking at and dealing with risks in the industry [48]. Following the Deepwater Horizon disaster in the Gulf of Mexico in 2010, the PSA introduced the principles for barrier management in the petroleum industry, calling for a more proactive safety approach that underlined the need for a sound HSE culture, improved management systems, and robust solutions [49].

Like the petroleum industry, the regulatory approach in the construction industry is functional, but the development of regulations was not related to specific accidents. There are three main laws and regulations that, to a large degree, set preconditions on safety: The Working Environment Act [44]; the Internal Control Regulations [50], following the internal control principle from the petroleum industry; and the Construction Client Regulations [51], which were based on a European Council Directive and aim to protect workers from risks, giving responsibility for safety to clients and designers. In addition, there is a set of regulations that elaborates the Working Environment Act. Some of these are detailed regulations; e.g., concerning assembly and use of scaffolds. All the regulations are minimum requirements, and some actors have more stringent requirements.

The tripartite collaboration and cooperation between the government, employers, and labour unions stands firm in Norwegian working life. In the petroleum industry, this collaboration is exercised in arenas such as the Regulatory Forum (RF), the Safety Forum (SF), Working Together for Safety (SfS), and the HSE Managers Forum (HMF), which also organises the network for safety and emergency response training [52-54]. Concerted efforts have resulted in the development of uniform rules for issuing work permits and performing Job Safety Analysis (JSA) of installations. Similarly, and in part inspired by the petroleum industry, the construction industry signalled its intentions to improve safety in 2014 through the "Charter for an injury-free building and construction sector", later called "Working Together for Safety in the construction industry" (SfS BA) [55].

\subsection{Environmental Stressors and Trends}

These two industries and the safety of the workers are affected by numerous factors in their environment outside of their control. Hovden [39] highlights the threats to safety from changing market conditions and technological change, such as economic optimisations that have reduced safety margins, and a more robust infrastructure in the industry, which might reduce motivations to keep safety up to the same level. The price of oil strongly influences the operating margins in the petroleum industry. In the 1990s, as a consequence of the decline in oil prices and reduced revenue, the Norwegian Offshore Cost-Effective Initiative (NORSOK) was introduced with an aim of reducing costs while maintaining HSE, initiating technological developments, and making changes in organising the industry and the development of standards [39]. However, this also altered market conditions and challenged power balances in the tripartite collaboration through changed relations between actors [56]. The financial downturn in 2009 affected both industries, with a decrease in employment and output of goods and services [57]. In 2013, the petroleum industry experienced a fall in oil prices and production, resulting in cost cuts and decreased employment, activities, and investments [3,57]. The 2015 RNNP report revealed that NCS workers experienced that production considerations came before HSE, and inadequate maintenance affected safety negatively [58]. Whether or not a regulatory regime succeeds depends more on the political climate and public awareness than the scientific basis for enforcing alternate administrative principles of regulation and control [39]. In the 
construction industry, the largest value creation is during the construction phase, when the operating margins are at their lowest, on average being around 3.6\% [59].

The changing conditions in the market and available resources have also affected these two industries. Since early 2000, several small and medium-sized companies entered the NCS, contributing to changes in the petroleum industry's composition [30]. A prequalification system was established to cope with this change. In the construction industry, a substantial change occurred after the opening of EU borders in 2004, when the number of migrant workers from Eastern Europe started increasing [60]. In the years 2012-2018, more than one-third of the fatal accidents in the industry involved foreign citizens [8]. Furthermore, several of the fatal accidents (around 25\% in the years 2012-2018) in the construction industry occurred to persons not employed directly in the construction industry, but through a temporary work agency or in another industry [8], which highlights an additional factor affecting the industry: hired labour.

New trends such as competition from shale-oil production, lower production prices in the global market, lower production costs of renewable energy, and decreasing resources on the NCS further pressure the petroleum industry [61]. Although recent trends are not necessarily negative for accident risk, the lack of knowledge about the interactions of these trends is problematic [39]. Fast-paced technological developments in the petroleum industry can contribute to improved safety, but also bring in new challenges [62]. In the construction industry, technological developments, regulations, and improvements in emergency treatment have contributed to safer sites in recent years. The developments also involved a change of perception; what was earlier perceived as safe enough is today considered unsafe. However, dangerous work tasks and risks due to increased complexity still influence safety. The industry remains bedevilled by challenges related to hired labour, social dumping, and fragmentation of responsibilities [63].

\subsection{Summing Up Characteristics of the Two Industries}

Figure 4 summarises and compares characteristics of work and framework conditions in the two industries by using Rasmussen's model [22] based on the descriptions in Sections 2.1-2.4. Inside the boxes, divided by actor groups, industry facts and framework conditions that can affect safety are listed. Additionally, outside the boxes, examples of environmental stressors are summed up.

An examination of Figure 4 reveals the significant differences between the nature of the two industries across all levels from Rasmussen's perspective. Government influence at the top is greater and clearer for the petroleum industry, where there is a recurring and explicit ambition of the Norwegian Government for the industry to be a world leader on HSE $[36,64]$. The scope and resources for the two regulatory authorities again are drastically different, with the PSA focussing mainly on safety in just the petroleum industry, and the NLIA having its focus on safety in multiple industries. Furthermore, in the petroleum industry, major accidents have changed the political climate and public awareness, which have in turn changed regulations.

In both industries, there are several levels of actors that, through their actions, produce important framework conditions for other actors. Decisions, budgets, and plans from one actor can become framework conditions for other actors [23]. The number of operating companies is also significantly different. While cost-cutting has affected the petroleum industry in the past years, small operating margins have traditionally been a characteristic of the construction industry. This plays a significant role as an external stressor in the way companies and management work with safety. Structural conditions in the company affect how accident risks are managed-for example, size affects the communication patterns and the need for advanced safety management system, or resources in terms of affording safety solutions and safety personnel [18].

Differences between the industries in social climate, such as trust in regulatory institutions and political and regulatory culture (or style), might affect how risk is governed within the two industries [65]. 


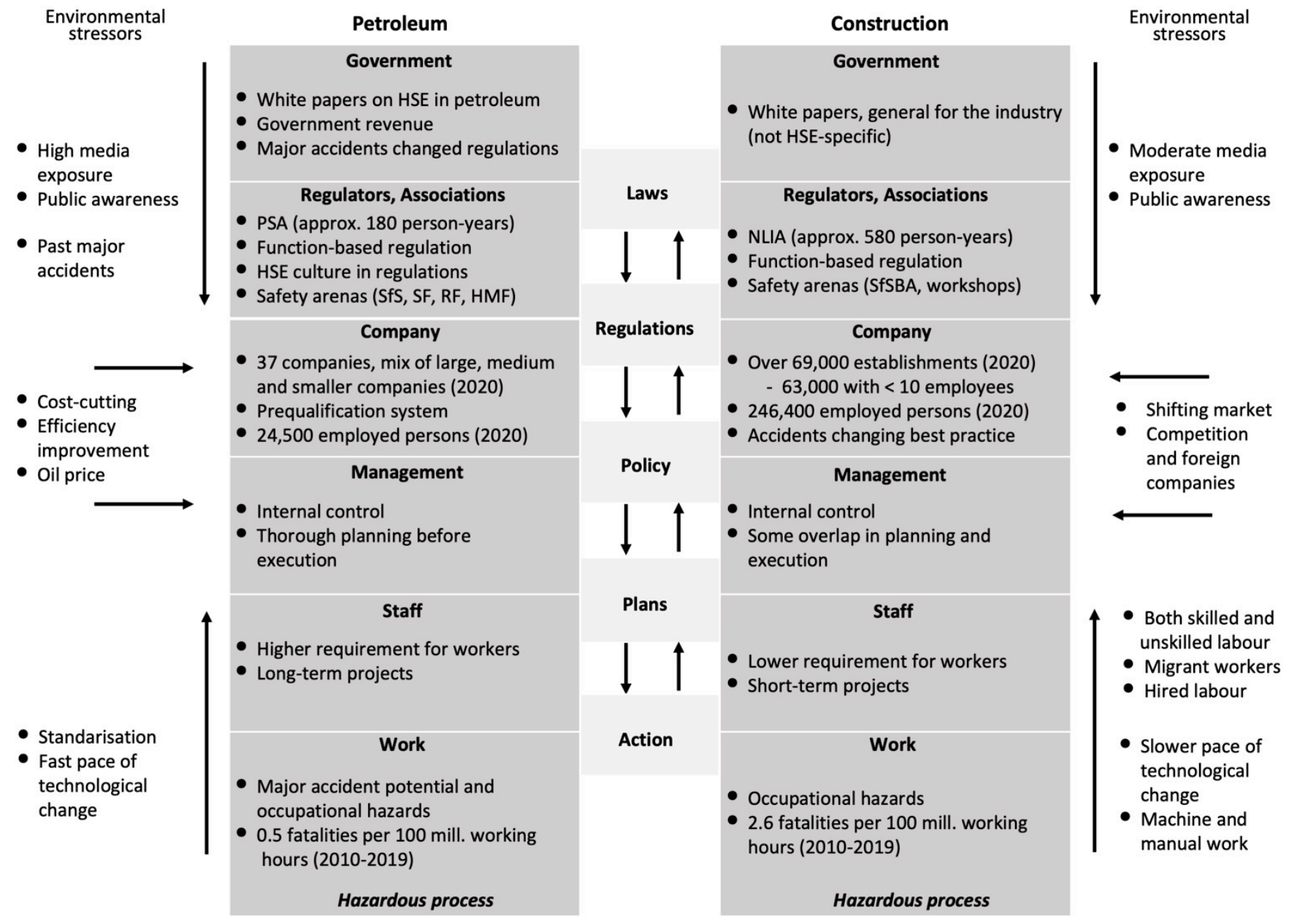

Figure 4. A generic perspective on the petroleum and construction industries. Based on Rasmussen's model [22].

\section{Materials and Methods}

\subsection{Data Collection and Analysis}

This qualitative study was based on semi-structured interviews with stakeholders in the construction and petroleum industries to give insight into aspects influencing safety performance and development in the two industries. The nature of qualitative studies is to gain insight, rather than to generalise to facts. The practices and opinions from the interviews contribute to nuances, which without the interviews are difficult to capture. A semi-structured approach was chosen as it offers flexibility and room for elaboration and clarification during the interview [66]. The interviews were conducted in 2017 and 2019. Documents, reports, and statistical data were used as background information. The factual and empirical data complement each other in shedding light on safety related aspects.

Rasmussen's model was used as a starting point for the research design to ensure that all important levels influencing occupational safety at the sharp end, as well as important framework conditions, were included. The interviewees were from four different levelssupervisory authorities, employer and employee organisation representatives, company management, and company safety personnel. This spread of viewpoints and experiences made the data comprehensive and contributed to a broad understanding of safety practices in the two industries.

The selection of interviewees was based on purposive sampling, which is suitable for in-depth studies, as it aims to provide rich information through participants with required status, experience, or knowledge [66,67]. The selection criteria of the respondents were organisation type (i.e., safety authorities, employer and employee organisations, and petroleum and construction companies), employment position (for companies-top 
management, safety manger/coordinator), and a focus on hands on experience in the industry. Further, participants within the criteria with experience from both industries were especially targeted. Snowball sampling, in which new contacts were recommended by other interviewees [66], was used to some extent to recruit participants.

The interviewees had from 3 to over 20 years' experience in the petroleum industry, with the majority between 10-30, and between 3 and 15 years in the construction industry, with the majority being around 5-10 years.

An interview guide was made with adapted questions for the four different types of interviewees. The interview guide included (but was not limited to) the following topics: perceived level of safety in the industry; challenges in the industry that may affect safety; influences from different levels of actors; relationship between the safety authority, industry, and the workforce (tripartite collaboration); views on the respective safety authorities; and where relevant, a comparison of safety management across the two. During the last interviews, a saturation point for the main questions in the interview guide was reached, with no more new, relevant data emerging [68], indicating a sufficient sample size.

Table 1 shows the number of interviewees from each industry and the four categories covered. In total, there were 36 interviewees in the study, of which 33 were interviewed and 3 answered questions by e-mail. Some interviews were in person, while most were conducted via phone and lasted between 0.5 to $1 \mathrm{~h}$. Of the interviewees, 18 had experience in both industries. All of the interviews were conducted in Norwegian. Most of the interviews were recorded and transcribed, except for a few. These interviews were conducted by two interviewers and detailed notes were written during the interview.

Table 1. Number of interviews for each industry.

\begin{tabular}{lcc}
\hline & Petroleum Industry & Construction Industry \\
\hline Safety authorities & 3 & 2 \\
Employer and employee & 7 & 3 \\
organisations & & \\
Top management & 3 & 4 \\
Safety personnel & 5 & 9 \\
Total & 18 & 18 \\
\hline
\end{tabular}

The transcribed data were coded based on categories from the interview guide and through open coding, in which new categories were found. The coding of the data was performed in parallel by two researchers to ensure a correct basis for the analysis. The data used for quotations were translated by the authors from Norwegian to English. The transcribed and coded data were analysed systematically by categories with the research questions in mind, which resulted in state-of-the-art descriptions of the safety in the two industries, a comparison between them, framework conditions affecting safety in the two industries, and the learning potential.

In summary, the comparison of the industries was based on information from workers in each industry, comparison by the workers who had experience in both industries, as well as factual information from statistics and documents about the industries. This allowed for triangulation of the analysed data, in which findings could be crosschecked [67].

\subsection{Delimitations and Limitations}

To compare the two industries, this paper is limited to looking at framework conditions that were comparable between the two industries related to factors that affected the level of safety, such as the economy, authorities, and management. Factors specific to each of the industries, such as contracting models in construction and how they affect safety, were beyond the scope of this study.

A comparison of safety in the construction industry during the building phase and the petroleum industry in the operating phase is not straightforward. The aim was to look at safety from a generic perspective in both industries. However, there were large variations 
within the industries that needed to be taken into consideration when interpreting the results. As there are, in practice, many influences from one industry to the other, a comparison between the two industries was rationalised.

\section{Results}

The empirical results indicate aspects affecting safety. The results are divided into the general safety level of the two industries, influences on safety from different actors, and influences between the two industries.

\subsection{The Safety Level in the Norwegian Petroleum and Construction Industries}

The interviewees from both industries perceived the petroleum industry to have a higher level of safety than the construction industry. The interviewees varied in their perception of the construction industry's general safety level. One interviewee compared the safety in the construction industry to the safety in the petroleum industry in the 1970s and 1980s. Overall, the safety level in the construction industry has improved in recent decades. However, several interviewees agreed that the industry still has potential for improvement. As one interviewee from an employer organisation in construction said: "Actually it is quite good, but not good enough".

Many attributed the high safety focus in the petroleum industry to major accidents. In contrast, the focus in construction is primarily on occupational safety, as the industry evaluated the risk of major accidents as being relatively lower. Fatal accidents in construction usually result in improvements within a project in a company, rather than impacting the whole industry. However, a few examples of accidents impacting the entire industry were found, such as a bridge collapse in Trondheim in 2013, which was said to have ended the practice of keeping roads open for public traffic below concrete work. Another example mentioned was large contractors demanding machinery re-design after accidents.

Many interviewees also attributed the higher safety level in petroleum to a better economy that allowed for more resources to be allocated to safety. Several interviewees noted that due to low oil prices, cost-cutting has resulted in a backlog of facilities maintenance. The interviewees also underlined that many offshore facilities are reaching their life expectancies, and modifications to extend their operations could impact safety.

\subsection{Safety Influences from Different Actors}

This subsection presents the findings on how different levels of actors and related factors influence occupational safety in the two industries, structured according to Rasmussen's socio-technical model [22], starting from the government at the top, moving down towards staff and the work itself.

\subsubsection{Government}

The top level of the framework involves control of safety through the legal system. Legislation and the use of standards were identified as important factors influencing safety in the petroleum industry. The regulations in the petroleum industry are trust-based and were perceived as good by the interviewees, providing a common goal for the industry. However, some claimed that trust-based regulations do not work well during financial downturns.

In the construction industry, some argued that not all of the regulations were beneficial for safety. Others found the regulations to be too bureaucratic. It was also mentioned that the formulations should be stated more clearly to avoid varying interpretations of the regulations. Some interviewees argued that the regulations already were good, and the problem lay in using them in practice.

Changes in the regulations allowing the use of temporary workers have resulted in an influx of foreign, contingent workers in both industries. 


\subsubsection{Regulators and Associations}

There was no common agreement among the interviewees on how the regulators influenced safety in their respective industries. Although both regulators utilised similar sanctions and measures, the interviews indicated a difference in the degree to which different sanctions and measures were used and in the way they conducted audits. The NLIA conducted both announced and unannounced inspections (sometimes referred to as "actions"), while the PSA operated under announced audits. Offshore constraints (in terms of transport scheduling and capacity) necessitated the announcement of when the PSA audits would take place. There was consensus among the interviewees that the NLIA's resources were meagre compared to the PSA's, despite their wider area of responsibility. As a result, there can be long periods between the NLIA's visits to the same construction company. Some added that the NLIA is often limited to supervising large companies that already have good systems in place, instead of focusing on smaller companies. The NLIA was also perceived as being somewhat reluctant to fine companies that do not follow regulations. According to some interviewees, this may be due to the observation that fines are ineffective in getting rid of unscrupulous actors. A large fine could easily break small but serious companies, whereas less-serious actors can simply start over by declaring bankruptcy.

The development of the NLIA's safety work was perceived as adequate by several interviewees. Workshops that the NLIA holds together with the industry were perceived as very positive. It was highlighted that the PSA's reports from inspections are made public, which puts a high focus on sharing and learning between companies in the petroleum industry. One interviewee emphasised the active role that PSA plays in the safety level of the industry:

"They [PSA] are professionally good. [ ... ] They always come with some improvement points. We do not always agree with each other, but I find that the PSA helps to keep up the standard. They help to make us good. They are important to the industry, I think."

(Manager, Petroleum)

Not everyone shared this view of the PSA. Some interviewees found the PSA to be weaker than the NLIA, pointing to the PSA's inadequate supervision and restrictive use of sanctions on oil companies. Others stated that the PSA had lost the unions' trust, as they seem to accommodate the companies too much. Others again experienced the PSA as not clear enough when it comes to their safety requirements.

"If you look at the NLIA, they have stopped 50 workplaces in one year. The PSA has in the last 20 years barely stopped anything."

\section{(Employee and employer organisation, Petroleum)}

Traditionally, the trade unions have been influential in the petroleum industry. While some mentioned that the collaboration between employer and employee associations and organisations is positive for HSE, others pointed out that the financial downturn has affected the position of the trade unions, decreasing their capacity to influence.

"It is the mainstay of the Norwegian industry-it [the tripartite collaboration] is seen as a success factor. But the truth is that we feel it has become more and more challenged. They want us not to have so much influence."

\section{(Employer and employee organisation, Petroleum)}

For the construction industry, no notable aspects or opinions were presented regarding trade unions, except the role of safety deputies. Some perceived the role of safety deputies in construction as having less influence and a lower reputation than in the petroleum industry. The higher level of risks offshore and the higher costs in petroleum if something goes wrong were given as potential reasons for this by the interviewees. 


\subsubsection{Company Level}

The oil companies and clients in the construction industry are influenced by actors above them and are in a position to influence actors on lower levels, such as operators, contractors, and sub-contractors. In the petroleum industry, the safety procedures are set from the top, by the oil company and the operators. Procedures and requirements were described by the interviewees to be, overall, similar within the industry, often based on standards such as NORSOK, which are stricter than the Working Environment Act. In the construction industry, the companies primarily aspired to achieve the minimum standards set by the regulations. It was also stated that a client could operate with internal HSE rules for their own employees and external HSE rules for contractors. One reason for this was not to intrude into the contractor's work methods and procedures. Looking at the construction industry as a whole, procedures and rules therefore vary somewhat between companies, although they fulfil regulatory requirements. One interviewee mentioned that the larger contractors in construction have systems that are similar to that in the petroleum industry. However, there are large variations in the construction industry-for example, between small and large companies, public and private clients, and even between different projects in the same company. It was mentioned that, in construction, both the reporting system and the reporting culture are not as well developed as in the petroleum industry. Others mentioned leniency in terms of local choices and adaptations and less severe sanctions for HSE rules not being followed than in the petroleum industry.

"In the petroleum industry similar rules and procedures generally apply. In the construction industry, on the other hand, in my company we have an external HSE towards the contractor and so on, and an internal towards our own employees."

(Safety-responsible, Construction)

Prequalification of companies (e.g., contractors and sub-contractors) is the norm in the petroleum industry, including assessment of HSE results from earlier projects. In the construction industry, large clients and contractors use similar systems, but they are not as widespread as in the petroleum industry. Some interviewees pointed out that the smaller number of companies operating in petroleum enabled them to have more straightforward control of aspects such as worker competence, qualifications, and experience.

Continuity in the organisation was also identified as a factor influencing safety. While construction is generally project-based in its organisation, petroleum facilities usually comprise the same operative organisation for many years. Some also pointed to the dependencies between actors at construction sites and the possible resulting delays as having consequences for safety.

\subsubsection{Management}

The interviewees identified thorough planning of operations and highly controlled activities as factors promoting safety in the petroleum industry. Any change was regarded as a potential contributing factor to unwanted events.

Further, management was regarded by the interviewees as having an influential role for safety. All interviewees agreed that managers are role models and need to communicate clearly and insist that safety comes first. Leadership was indicated by many of the interviewees as an essential condition for safety. Several aspects of leadership were pointed out: making managers accountable rather than just responsible, stable relations between managers and workers, loyalty to safety systems by mangers, "anchoring" of safety systems in managers, and consequences for both workers and leaders if attitudes and actions are not correct.

"Something that characterises the construction industry is that there are no stable manger-employee relations." 


\subsubsection{Staff and Work}

In comparison to the construction industry, many interviewees described the petroleum industry as having stricter rules and a greater focus on understanding risks and emphasis on barrier thinking. In construction, attitudes towards safety and understanding of risk were described to be challenging, and the understanding of safety concepts was perceived as weaker than in the petroleum industry.

The significant number of contingent labourers that lack competence and equipment to perform the work safely in construction was indicated as another reason for the higher number of injuries and fatalities than in the petroleum industry. Such work practices were described as potentially affecting the establishment of relations and continuity in organisations, such as between managers and workers or between workers. In addition, in the petroleum industry, the use of hired labour is also becoming more common, especially in land facilities. Some noted that these two industries are becoming more similar in terms of increased hired labour. Related to hired labour in construction, it was mentioned that it could be challenging to know who works on the site and with what competence. The randomness of temporary-worker composition was said to affect the possibility of incorporating these workers in the safety culture at the site. Proper training of workers, being familiar with the organisation, the importance of knowing each other, and continuity were highlighted in both industries as critical to safety.

"I see a development where more and more unskilled workers are coming from Eastern Europe who are willing to do the job on conditions which Norwegians cannot live off. I ... I If we can't turn this around and change this, then we will end up in a few years with the same conditions as they have in the construction industry."

(Employee, Petroleum)

\subsection{Influences between the Industries}

According to several interviewees, oil companies have influenced contractors in the construction industry through contract requirements. Large contractors that have previously worked for petroleum companies, for example in building onshore facilities or doing maintenance offshore, had incorporated some systems related to safety from the petroleum industry.

"At the end of the 1980s I would say a clear improvement happened, more systematising and routines for HSE. This happened in the contracting companies, and the reason was that the large contractors were getting building orders from the oil companies. The oil companies had requirements for systems and routines, which the construction contractors did not really have. So, the part of the construction industry that worked with the petroleum industry developed and improved HSE in construction."

\section{(Employer and employee organisation, Construction)}

The petroleum industry has experienced several oil-price crises that led to workforce reductions. During these periods, many workers and managers moved to other industries, such as construction. The petroleum industry has thus influenced the construction industry. Many tools, practices, and even regulations from the petroleum industry have been copied and adapted by the construction industry. It was, however, pointed out that framework conditions are different in the two industries, and not everything is directly transferable between them. Room for adaptations and an understanding of the circumstances and situations to comprehend the risks were also highlighted. It was also pointed out that sometimes the vocabulary in the two industries is different, meaning that the same safety words can in practice mean different things.

"After the oil crisis we got many persons from petroleum. [ ... ] They may have many good systems for reporting, but they have never been in construction. [ . . ] Some think you can transfer everything one to one, but that does not work. We need to think what to do differently, not just copy." 
When it comes to arenas for knowledge sharing, the petroleum industry has long had networks promoting safety, such as the SfS. With inspiration from the petroleum industry, the construction industry in Norway has now established the SfS BA. Many of the interviewees believed that this arena would improve safety in the construction industry.

Systematic work and standardisation were mentioned as key areas where the construction industry should continue to adopt practices from the petroleum industry. The use of JSA, for instance, was regarded as coming from the petroleum industry. Here, some interviewees mentioned a striking difference in the adoption of this practice. While JSA is used selectively in petroleum, there seems to be an excessive use of JSA in construction. Better planning was mentioned as another area where construction could learn from petroleum. The example given was that many aspects need to be in place and risk assessed before a work package is sent to offshore for execution, whereas in construction, a worker sometimes gets some necessary information only just before the worker is sent to work, and the job might not be sufficiently well planned.

All of the points mentioned about learning from each other were related to what the construction industry can learn from the petroleum industry. When asked what the petroleum industry could learn from the construction industry, the interviewees did not have anything to say or offer.

\section{Discussion}

The empirical findings indicated aspects that, according to the interviewees, influenced safety positively or negatively; these are summarised in Figure 5. In this section, important results that contribute to explaining the different evolvement of safety in the two industries and point on improvement potential are discussed.

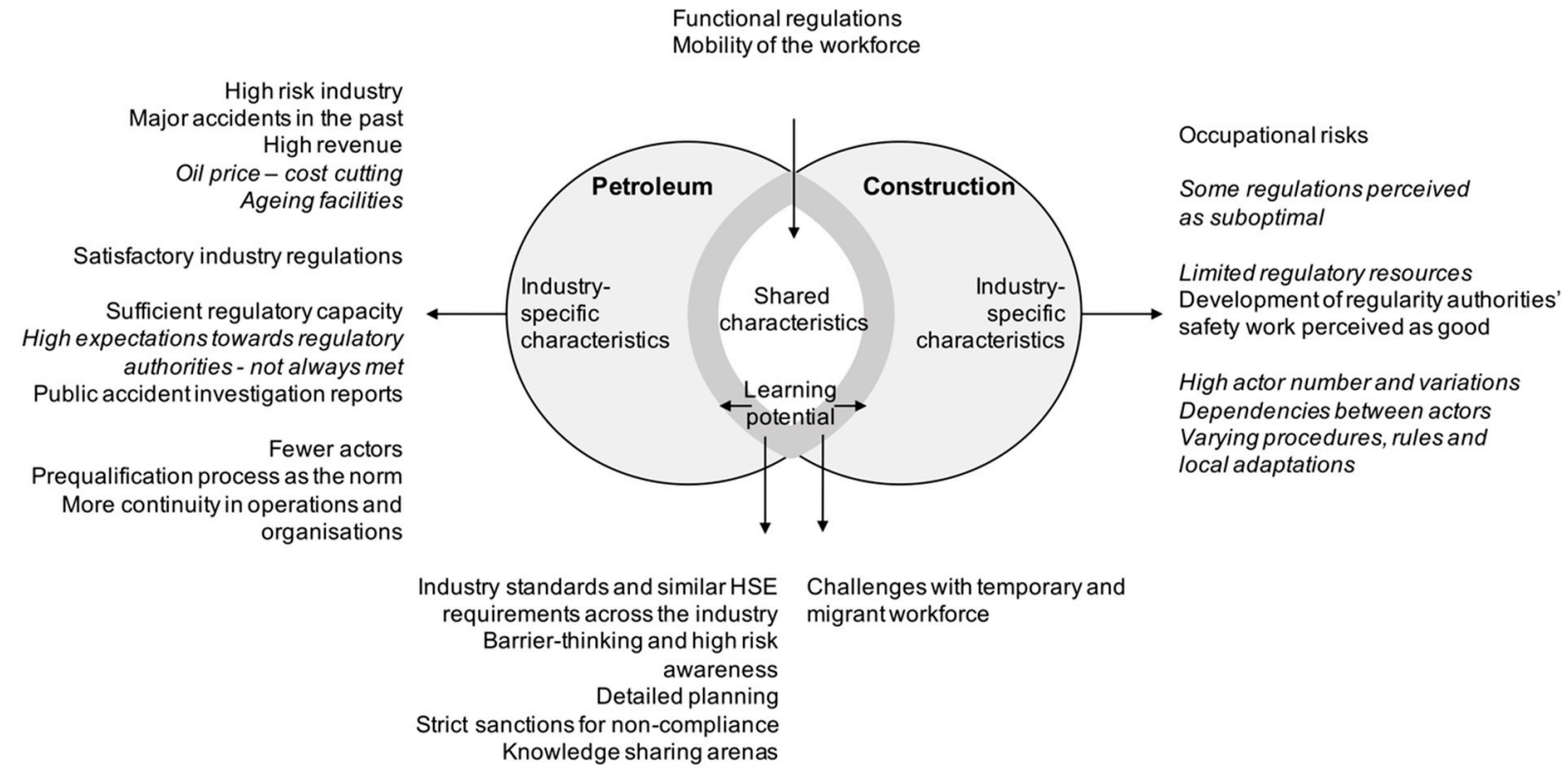

Figure 5. Aspects influencing safety and learning potential between petroleum and construction (aspects that can have a negative influence on safety are marked in italic).

\subsection{Development of Safety Work in the Two Industries}

Construction was a developed industry long before the petroleum industry began its operations in Norway. Safety in the two industries has been and is still under development. Worker protection to regulate safety began playing a role in Norway and in Europe in the 1890s, and the central Working Environment Act came into force in 1977 [63]. The approach to safety at the start of the petroleum industry in Norway in the early 1970s has, over the decades, changed and developed [39,69], contributing to the industry becoming a leader in 
Norway on safety today. Explicit expectations from the government towards HSE [64] put pressure on the petroleum industry and contributed to this development.

The petroleum industry is perceived by the interviewees as being more mature in terms of safety than the construction industry. To a large degree the focus on safety and the culture for prioritising safety are shared across all levels in the petroleum industry. The results indicate that the organisations in the petroleum industry have strict procedures for activities, substantial changes to planned operations require new risk assessments and procedures are revised according to the management of change procedures. Ad-hoc solutions have no place in their operations, in contrast to the construction industry, where workers may feel compelled to devise local adaptations as situations arise.

\subsubsection{Major Accident Risk Prevention as a Driving Factor}

Major accidents have affected the level of safety in the petroleum industry and are a constant reminder of the inherent hazards associated with petroleum-related activities. These hard-earned lessons led to many safety developments [70], and have engendered a profound change in the regulations and safety-management systems of companies, as well as propelled technical innovations that help control risks in the industry [69]. The risk of major accidents might be perceived as larger than the risk of occupational accidents, and thus could give rise to new safety measures to prevent future accidents. Perceived consequences, such as those of major accidents, play a role in the demand for risk mitigation [71]. The changes in regulations have also influenced other industries, such as through the regulation on internal control of safety, which today in the construction industrytogether with the Working Environment Act and the Construction Client Regulations-are among the laws and regulations affecting workers' safety the most. The results indicated that accidents in the Norwegian construction industry have not had a direct influence on regulations as in the petroleum industry, and the regulations in the construction industry are perceived as suboptimal. However, a few larger accidents have received more media and public attention, which influenced awareness within the industry and led to a change in best practices.

\subsubsection{Regulatory Resources and Tripartite Collaboration}

While regulations of both industries are functional, the results indicate variations in how they are enforced by regulators, such as in the use of sanctions, and how often inspections and audits are conducted. The disparity between the ideal regulatory activities and the actual resource at hand has repercussions on the performance of the safety regulators, making one regulator (PSA) more fortunate than the other (NLIA). The regulatory authorities are important for safety, but the interviewees' opinions fluctuated as to the degree to which the authorities actually influence safety. According to findings from the Office of the Auditor General, the PSA's supervisory practices had a limited impact on companies' follow-up of HSE in the petroleum industry [64]. In the interviews, some perceived the PSA as being better in earlier days. It was also mentioned in the interviews that the PSA and NLIA have different resources available and different supervision styles, and that the PSA is only responsible for the petroleum industry, while the NLIA has many industries to oversee, which could influence safety in the industry. Tripartite collaboration also seemed to differ between the industries. In general, it has an important role in the Norwegian working life, but the development and degree of influence from associations were indicated by the interviewees to be higher in the petroleum industry. The weaker impact of the associations could contribute to the explanation of the different safety levels in the two industries, through the impact on safety at the sharp end.

\subsubsection{Wide Range of Actors}

The petroleum industry consists of a modest number of companies and a few global actors, which pales in comparison to the number of companies in the construction industry, which consists of everything from individual enterprises to large, international enterprises. 
The large number of small companies in the construction industry was indicated to challenge the overall development of safety in the industry, as common attitudes, norms, and values are needed. It was pointed out that the large companies lift the small companies to a certain degree, but the variations within the industry are large. Although there are differences between companies offshore, the interviews indicate that requirements, systems, and organisational structures are more standardised in the petroleum industry than within the construction industry, which promotes a more similar safety level across the industry. Antonsen et al. found in a case study that an implemented standardised operation model for offshore installations positively influenced planning of tasks and compliance with procedures [72].

However, since the beginning of the 2000s, the composition of companies in the petroleum industry has changed, with new, less-experienced companies and smaller companies entering the NCS. The interviews indicated that collaboration and communication could vary from project to project, and may become more challenging as the number of firms increases. This diversity can challenge the industry's overall safety level, as more actors need to adapt, comply, and develop a similar HSE culture, and authorities have to adjust and follow up with the new actors as well. Ambiguities in roles and responsibilities between personnel from different companies have been found to be a factor contributing to occupational accidents and major near-accidents in the petroleum industry [73]. Regulations that demand a good HSE culture through continuous HSE work might support this [45]. In addition, the characteristics of the construction industry, being project-based, multi-tiered and with changing worker compositions, can result in short-lived interactions and lack of continuity. Since the workers are at each construction site for a limited time, this can reduce the opportunity for developing shared norms and practices.

Aspects such as employment condition also play an important role for safety, and the use of hired workers or non-standard forms of employment make it even more complicated. The interviews indicated that it is common to use hired labour in the construction industry, and it was also mentioned that foreign workers pose a challenge not only in terms of lingual issues, but also in terms of employment arrangements. The working arrangements are also changing in the petroleum industry. As stated in the interviews, more and more of the workers in the petroleum industry have temporary contracts, as in the construction industry. A review of earlier studies showed that temporary agency workers have a higher occupational health and safety risk, including higher injury rates [74].

\subsubsection{Ensuring Continuous Improvement}

Although the safety level has improved over the years in both industries, they continuously strive to improve. In the construction industry, this can be seen in the eagerness to learn from the petroleum industry; e.g., adopting tools and practices, and creating SfS BA. For the petroleum industry, however, trends such as unstable oil prices, organisational change (e.g., hired labour), and already operating at a high safety level might make it harder to develop safety further at the same pace. This could lead to an "attention withdrawal" by the top management, in which attention to safety and safety performance can gradually decrease [75]. Furthermore, some of the interviewees argued that the apparent economic differences in revenue can no longer be used as a reason or excuse for less-developed safety in the construction industry, as the petroleum industry currently does not have the same economic resources as previously.

\subsection{Transferable Experiences and Knowledge}

The petroleum and construction industries in Norway are distinct, but these two industries can potentially learn from each other. For the construction industry, an opportunity to learn from the safety-management systems in the petroleum industry was previously identified, especially related to knowledge management, in an earlier study [76]. Broadly speaking, the construction industry is looking up to the safety level and practices of the petroleum industry. 


\subsubsection{Petroleum as a Role Model}

Analysis of the empirical data points to several influences from the petroleum industry on the construction industry's safety. The construction industry has benefitted from the experiences and knowledge developed for and in the petroleum industry, including safetymanagement tools such as incident-reporting systems, risk-assessment tools (e.g., JSA) or frequent meetings at the sharp end. Several arenas have been established to share safety knowledge and experience in the construction industry, such as conferences, workshops, and forums. For example, inspired by the SfS network in the petroleum industry, the construction industry established a similar network-SfS BA.

\subsubsection{Adoption of Practices}

Regarding standardisation, it seems that the construction industry is moving towards practices from the petroleum industry related to more uniform safety tools, methods, and practices across companies, and more uniform requirements across large clients and contractors. The fact that some construction companies have been working for oil companies has helped them adapt parts of their safety practices to the stricter practices in the petroleum industry, which slowly seem to be becoming an industry standard. These similar characteristics may be created through various institutional pressures, resulting in isomorphism [77]. Movement of petroleum workers to the construction industry, coupled with the transfer of practices and tools, such as toolbox talks, barrier-oriented thinking, and standardisation, may have resulted in the diffusion of ideas.

There is, however, reason to believe that the outright transfer of knowledge from one industry to another is not straightforward. The indiscriminate use of JSA in the construction industry, for example, has reached a point where its adoption runs the risk of losing value and function [78]. All measures are not necessarily suitable, and practices need to be translated and adapted to the industry and prevalent conditions. It was pointed out by several interviewees that not everything could be directly copied and expected to work in the same way in the two industries. First, the understanding and perception of safety and the industry itself is in some cases different between the two industries. It was also seen from the interviews that not all framework conditions necessarily behave the same way in the two industries. This was also observed in the varying trends between the two industries, perhaps attributable to their distinct safety levels. The risk picture in the two industries is different, and thus the need for measures will also differ. It is therefore crucial to adapt different measures, concepts, tools, and policies and the like to the industry's framework condition, needs, requirements, and competence, rather than directly transferring them and taking for granted that they are the same in the two industries. The differences between companies within the industries, where the differences are larger within construction than within the petroleum, are another consideration. For the construction industry, it might be wise to mature at the industry's own pace when it comes to safety and not necessarily rush into adopting solutions that have worked in petroleum.

\subsubsection{Technological Innovations}

From the analysis, it was prominent that there were trends related to the structural systems that can influence safety. Some framework conditions are stable and cannot easily be changed, such as the size of companies, the number of companies, and regulations. Technological developments have been fast in the petroleum industry, and at present also are becoming increasingly rapid in the construction industry, thus requiring constant adaptation. The extensive use of automation and barriers that characterise petroleum activities are features that remain wanting in the construction industry. However, many developments are coming that are related to, for example, digitalisation. The new developments will introduce new possibilities, but also challenges and more complexity. Many of these developments are also somewhat generic for both industries. In terms of safety management, experiences with technological developments and digitalisation could be shared and learned across the two industries. 


\subsubsection{Experiences from Construction to Petroleum}

The already high level of safety in the petroleum industry seems to prevent many from identifying learning opportunities from the construction industry. The interviewees in the petroleum industry had a rather pretentious attitude towards possible learning points from construction. However, the construction industry has a lot of experience, for example with migrant workers and temporary contracts, that could also be of value for the petroleum industry in the future. The caveats that come with a growing population of migrant and temporary workers coupled with ageing facilities and the emerging effects of peak oil should be brought to the petroleum industry's attention and resolved, with the same ambition that brought about the industry's high level of safety.

\section{Conclusions}

The construction industry has a significantly higher fatal accident rate than the petroleum industry in Norway. Through a systematic, qualitative, interview-based study with actors across both sectors and organisational levels, this paper has elaborated reasons for the different safety levels between the industries. The paper has also identified and discussed further potential for improvement across the two industries. The novelty of the study is the comparison with an inter-industry perspective, and a focus on transferable experiences given the influencing characteristics and conditions.

The petroleum industry is primarily perceived as having a more mature level of safety. In the construction industry, there are large variations in the safety level between companies. The safety developments in the petroleum industry have largely been accelerated by several major accidents, which brought changes in the regulations and increased the focus on safety, which is not the case in the construction industry. The interviews indicate that procedures and requirements in the petroleum industry are more standardised and similar for all actors within the industry, as compared to the construction industry, where the companies primarily aspire to achieve the minimum standards set by the regulations. The interviews further point to structural differences, in particular the large number of actors in the construction industry, as challenging for a general level of safety and having similar practices across the industry. In addition, sharing lessons learned and other relevant safety information between companies in the petroleum industry are more systematic and frequent than in the construction industry.

Furthermore, the construction industry has benefitted from safety improvements in the petroleum industry, such as tools and methods, through interaction between the two industries; e.g., movement of people and contractual requirements. Nevertheless, the interviewees from the construction industry all agreed that better planning, standardisation, and barrier-thinking more similar to those implemented in the petroleum industry could improve the industry's level of safety. Furthermore, the technical developments and knowledge sharing are more developed areas in the petroleum industry. The petroleum industry has to further strive to maintain and evolve its safety levels, given possible changes and new developments, and might also benefit from looking into experiences across sectors; e.g., the construction industry's experience with the temporary and migrant workforce.

Author Contributions: Conceptualization, K.W.E. and M.N.; methodology, K.W.E. and M.N.; investigation, K.W.E. and M.N.; formal analysis, K.W.E. and M.N.; writing-original draft preparation, K.W.E., M.N. and E.A.; writing-review and editing, K.W.E., M.N. and E.A.; visualization, K.W.E. and M.N. All authors have read and agreed to the published version of the manuscript.

Funding: This research received no external funding.

Institutional Review Board Statement: The study was conducted according to the guidelines of the Declaration of Helsinki, and approved by the Norwegian Centre for Research Data (NSD) (ref. no. 56954, 23 November 2017).

Informed Consent Statement: Informed consent was obtained from all subjects involved in the study in accordance with the NSD's requirements. The participation was voluntary, and the interviewees were informed about the right to withdraw. 
Data Availability Statement: Data supporting the findings are available within the article. Additional data is not publicly available due to the nature of this research.

Acknowledgments: Time to work on this paper was funded by the Department of Industrial Economics and Technology Management (NTNU), as a part of a PhD, and NTNU Social Research, Studio Apertura. We wish to thank all the interviewees for participating in the study, and anonymous reviewers for valuable feedback.

Conflicts of Interest: The authors declare no conflict of interest.

\section{References}

1. SSB. Statistics from STATBANK: 10913: Fatal Accidents at Work, by Regulatory Authority and Industry (SIC2007) $2000-2019$. Available online: https:/ /www.ssb.no/en/statbank/table/10913 (accessed on 24 March 2021).

2. NPD. Utvikling i Risikonivå-Norsk Sokkel. Pilotprosjektrapport for 2000 [Development of Risk Level-Norwegian Continental Shelf. Pilot Project Report for 2000]; Norwegian Petroleum Directorate: Stavanger, Norway, 2001. Available online: https:/ /www.ptil.no/ contentassets/08f11ad6277b4a248358350dc5221c6e/ pilotprosjekt---hovedrapport2000.pdf (accessed on 24 March 2021).

3. PSA. Risikonivå i Petroleumsvirksomheten. Hovedrapport, Utviklingstrekk 2019, Norsk Sokkel [Risk Level in the Petroleum Activities. Main Report. Development Trends 2019, Norwegian Continental Shelf]; Petroleum Safety Authority Norway: Stavanger, Norway, 2020; Available online: https: / / www.ptil.no/fagstoff/rnnp/rnnp-2019/hovedrapport/ (accessed on 24 March 2021).

4. SSB. Construction etc. 1970-1977; Central Bureau of Statistics: Oslo, Norway, 1979. Available online: https://www.ssb.no/a/ histstat/nos/nos_b028.pdf (accessed on 24 March 2021).

5. SSB. Statistics from STATBANK: National Accounts. 09174: Wages and Salaries, Employment and Productivity, by Industry 1970-2020. Available online: https://www.ssb.no/en/statbank/table/09174 (accessed on 15 May 2021).

6. SSB. Statistical Yearbook (1880-2013) Official Statistics of Norway; Central Bureau of Statistics: Oslo, Norway, 2013. Available online: https:/ / www.ssb.no/a/histstat/aarbok/ (accessed on 11 March 2021).

7. Winge, S.; Albrechtsen, E. Accident types and barrier failures in the construction industry. Saf. Sci. 2018, 105, 158-166. [CrossRef]

8. Gravseth, H.M.; Mostue, B.A.; Winge, S. Ulykker i Bygg og Anlegg-Rapport 2019 [Accidents in Construction—Report 2019]; The Norwegian Labour Inspection Authority: Trondheim, Norway, 2019. Available online: https:/ /arbeidsmandsforbundet.no/wpcontent/uploads / 2019/11/Ulykker-i-bygg-og-anlegg-Rapport-2019.pdf (accessed on 24 March 2021).

9. PSA. Granskning av Hendelse «Mann over Bord med Dødelig Utfall på Saipem 7000 12.08.2007. [Investigation Report of Incidents 'Man Over Board with Fatal Result at Saipem 7000, 12 August 2007]; Petroleum Safety Authority Norway: Stavanger, Norway, 2007.

10. PSA. Granskingsrapport Etter Ulykken på Oseberg B 7.5.2009 [Accident Investigation after the Accident at Oseberg B 5 May 2009]; Petroleum Safety Authority Norway: Stavanger, Norway, 2009; Available online: https:/ /www.ptil.no/contentassets/d2fe2fb5 adaa4e189e33a9b1017de224/granskingsrapport-doedsulykke-oseberg-nettversjon.pdf (accessed on 30 March 2021).

11. PSA. Investigation of an Incident with Fatal Consequences on COSLInnovator, 30 December 2015; Petroleum Safety Authority Norway: Stavanger, Norway, 2016; Available online: https://www.ptil.no/contentassets/34ba6b722c0c44a3a137240bae06f623 /investigation-report---cosl-drilling---cosl-innovator.pdf (accessed on 30 March 2021).

12. NPD. Utvikling i Risikonivå-Norsk Sokkel. Hovedrapport Fase 3-2002 [Development in Risk Level at the Norwegian Continetal Shelf-Main Report Phase 3-2002]; Norwegian Petroleum Directorate: Stavanger, Norway, 2003. Available online: https://www.ptil.no/ contentassets/7cb428e084454f7faf909712991e3e7b/risikonivhovedrapport2002.pdf (accessed on 24 March 2021).

13. PSA. Investigation Report Following the Fatal Accident on Maersk Interceptor; Petroleum Safety Authority Norway: Stavanger, Norway, 2018; Available online: https://www.ptil.no/contentassets/370f70c8df9547c696172cf82d0bf712/2017_1321_enggranskingsrapport-tambar-personskade-dodsulykke-maersk-interceptor.pdf (accessed on 30 March 2021).

14. Health and Safety Executive. Offshore Statistics \& Regulatory Activity Report 2019; Energy Division, Health and Safety Executive: Bootle, Merseyside, UK, 2020. Available online: https://www.hse.gov.uk/offshore/statistics/hsr2019.pdf (accessed on 30 March 2021).

15. PSA. Risikonivå i Petroleumsvirksomheten. Hovedrapport, Utviklingstrekk 2020, Norsk Sokkel [Risk Level in the Petroleum Activities. Main Report. Development Trends 2010, Norwegian Continental Shelf]; Petroleum Safety Authority Norway: Stavanger, Norway, 2021; Available online: https://www.ptil.no/fagstoff/rnnp/rnnp-2020/hovedrapport/ (accessed on 24 March 2021).

16. Mostue, B.A.; Nyrønning, C.Å.; Winge, S.; Gravseth, H.M. Ulykker $i$ Bygg og Anlegg-Rapport $2020 . \quad$ [Accidents in Construction-Report 2020]; Norwegian Labour Inspection Authority: Trondheim, Norway, 2020. Available online: https: / / www.arbeidstilsynet.no/globalassets / om-oss/forskning-og-rapporter/kompass-tema-rapporter/2020/kompasstema_nr2_2020-ulykker-i-bygg-og-anlegg.pdf (accessed on 24 March 2021).

17. Høivik, D. HSE and Culture in the Petroleum Industry in Norway. In Proceedings of the SPE International Conference on Health, Safety and Environment in Oil and Gas Exploration and Production, Rio de Janeiro, Brazil, 12-14 April 2010. [CrossRef]

18. Kjellén, U.; Albrechtsen, E. Prevention of Accidents and Unwanted Occurrences: Theory, Methods, and Tools in Safety Management, 2nd ed.; Taylor \& Francis: Abingdon, UK, 2017.

19. United Nations. Transforming our World: The 2030 Agenda for Sustainable Development; United Nations: New York, NY, USA, 2015; Available online: https://www.un.org/ga/search/view_doc.asp?symbol=A/RES/70/1\&Lang=E (accessed on 25 May 2021). 
20. Osei-Asibey, D.; Ayarkwa, J.; Acheampong, A.; Adinyira, E.; Amoah, P. Impacts of accidents and hazards on the Ghanaian construction industry. Int. J. Constr. Manag. 2021, 1-20. [CrossRef]

21. Lingard, H.; Wakefield, R.R. Integrating Work Health and Safety into Construction Project Management; Wiley Online Library: Hoboken, NJ, USA, 2019.

22. Rasmussen, J. Risk management in a dynamic society: A modelling problem. Saf. Sci. 1997, 27, 183-213. [CrossRef]

23. Rosness, R.; Blakstad, H.C.; Forseth, U.; Dahle, I.B.; Wiig, S. Environmental conditions for safety work-Theoretical foundations. Saf. Sci. 2012, 50, 1967-1976. [CrossRef]

24. Le Coze, J.-C. Reflecting on Jens Rasmussen's legacy. A strong program for a hard problem. Saf. Sci. 2015, 71, 123-141. [CrossRef]

25. Le Coze, J.-C. New models for new times. An anti-dualist move. Saf. Sci. 2013, 59, 200-218. [CrossRef]

26. Moan, T. Safety of Offshore Structures; CORE Report No. 2005-2004; National University of Singapore: Singapore, 2005.

27. SSB. Statistics from STATBANK; 10914: Reported Accidents at Work, by Sex, Age, Absence and Industry (SIC2007) $2014-2019$. Available online: https:/ /www.ssb.no/en/statbank/table/10914 (accessed on 24 March 2021).

28. Ministry of Petroleum and Energy. Norway's Oil History in 5 Minutes. Available online: www.regjeringen.no/en/topics/energy/ oil-and-gas/norways-oil-history-in-5-minutes/id440538/ (accessed on 8 May 2021).

29. Vatne, E. Sysselsetting i Petroleumsvirksomhet 2017. Omfang og Lokalisering av Ansatte i Oljeselskap og den Spesialiserte LeveranDØRINDUSTRIEN. [Employment in the Petroleum Industry 2017]; Centre for Applied Research at NHH: Bergen, Norway, 2018; Available online: https://www.regjeringen.no/contentassets/6cde1d4efca44c67a31c36ef98a1e4e8/r01_18.pdf (accessed on 25 March 2021).

30. Norwegian Petroleum. Diversity and Competition. Available online: https://www.norskpetroleum.no/en/developments-andoperations / number-and-diversity-of-companies / (accessed on 25 March 2021).

31. Norwegian Petroleum. The Service and Supply Industry. Available online: https://www.norskpetroleum.no/en/developmentsand-operations/service-and-supply-industry/ (accessed on 24 March 2021).

32. SSB. Statistics from STATBANK-10309: Establishments, by Activity Codes (SIC2007) and Number of Employees (M) $2009-2021$. Available online: https:/ /www.ssb.no/en/statbank/table/10309 (accessed on 24 March 2021).

33. Nykamp, H.; Skåholt, A.; Ørstavik, F. Sikkerhet i Komplekse Prosjekter [Safety in Complex Projects]; Nordic Institute for Studies in Innovation, Research and Education (NIFU): Oslo, Norway, 2011; Available online: https:/ / www.nifu.no/publications/866060/ (accessed on 10 March 2021).

34. PSA. Årsrapport 2020 [Annual Report 2020]; Petroleum Safety Authority Norway: Stavanger, Norway, 2021; Available online: https:/ / www.ptil.no/fagstoff/utforsk-fagstoff/fagartikler/2021/arsrapport-2020-annerledesaret/ (accessed on 10 May 2021).

35. Lindøe, P.H.; Engen, O.A. Offshore Safety Regimes-A Contested Terrain. In The Regulation of Continental Shelf Development; Brill I Nijhoff: Leiden, The Netherlands, 2013; pp. 195-212.

36. Bang, P.; Thuestad, O. Government-Enforced Self-Regulation The Norwegian Case. In Risk Governance of Offshore Oil and Gas Operations; Baram, M., Renn, O., Lindøe, P.H., Eds.; Cambridge University Press: Cambridge, UK, 2013; pp. $243-273$.

37. NLIA. Årsrapport 2020. En Analyse av Arbeidstilsynets Innsats i 2020 [Annual Report 2020]; Norwegian Labour Inspection Authority: Trondheim, Norway, 2021. Available online: https: / / www.arbeidstilsynet.no/contentassets/7ec576afb75a45b69f8a74705ebe9c1 8/arsrapport-2020.pdf (accessed on 10 May 2021).

38. NLIA. Arbeidstilsynets Satsing i bygg og Anlegg i Perioden 2013-2016 [The Norwegian Labour Inspection Authority's Initiative in Construction in the Period 2013-2016]; Norwegian Labour Inspection Authority: Trondheim, Norway, 2017. Available online: https:/ / www.arbeidstilsynet.no/globalassets/om-oss/forskning-og-rapporter/rapporter-fra-tilsynsprosjekter/ arbeidstilsynets-satsing-i-bygg-og-anlegg-perioden-2013-2016-2108-2017.pdf (accessed on 24 March 2021).

39. Hovden, J. The development of new safety regulations in the Norwegian oil and gas industry. In Changing Regulation: Controlling Risks in Society; Kirwan, B., Hale, A.R., Hopkins, A., Eds.; Elsevier Science Ltd.: Amsterdam, The Netherlands, 2002 ; pp. 57-78.

40. Lindøe, P.H.; Engen, O.A.; Olsen, O.E. Responses to accidents in different industrial sectors. Saf. Sci. 2011, 49, 90-97. [CrossRef]

41. Ryggvik, H. Offshore Safety Regulations in Norway: From Model to Systems in Erosion. NEW Solut. J. Environ. Occup. Health Policy 2000, 10, 67-116. [CrossRef] [PubMed]

42. Lindøe, P.H.; Baram, M.; Braut, G.S. Empowered agents or empowered agencies? Assessing the risk regulatory regimes in the Norwegian and US offshore oil and gas industry. In Advances in Safety, Reliability and Risk Management, Proceedings of the European Safety and Reliability Conference, ESREL 2011, Troyes, France, 18-22 September 2011; Taylor \& Francis Group: London, UK, 2012; pp. 1717-1724.

43. Petroleum Act. Lov om Petroleumsvirksomhet (Petroleumsloven) (LOV-1996-11-29-72). Ministry of Petroleum and Energy, Oslo, Norway. 1996. Available online: https:/ / lovdata.no/dokument/NL/lov/1996-11-29-72 (accessed on 24 March 2021).

44. The Working Environment Act. Lov om Arbeidsmiljø, Arbeidstid og Stillingsvern mv. nr. 62 av 17. Juni 2005. Ministry of Labour and Social Affairs, Oslo, Norway. 2005. Available online: https:/ lovdata.no/dokument/NL/lov/2005-06-17-62 (accessed on 24 March 2021).

45. Framework Regulations. Forskrift om Helse, Miljø og Sikkerhet i Petroleumsvirksomheten og på Enkelte Landanlegg. (FOR2010-02-12-158). Ministry of Labour and Social Affairs, Oslo, Norway. 2010. Available online: https://lovdata.no/dokument/SF/ forskrift/2010-02-12-158 (accessed on 24 March 2021).

46. PSA. About the Regulations. Available online: https://www.ptil.no/en/regulations/acts/about-the-regulations/ (accessed on 24 March 2021). 
47. Ministry of Labour and Social Affairs. St.meld. nr. 7 (2001-2002) Om Helse, Miljø og Sikkerhet i Petroleumsvirksomheten. [Report No. 7 to the Storting (2001-2002). On Health, Environment and Safety in Petroleum Activities]. 2001. Available online: https:/ / www.regjeringen.no/no/dokumenter/stmeld-nr-7-2001-2002-/ (accessed on 24 March 2021).

48. Lindøe, P.H.; Laudal, T. Delingen av Oljedirektoratet-et Svar på Målkonflikter i Petroleumsindustrien? [The Division of the Norwegian Petroleum Directorate - A Response to Goal Conflicts in the Petroleum Industry?]; Rogalandsforskning: Stavanger, Norway, 2004; Available online: https://norceresearch.brage.unit.no/norceresearch-xmlui/handle/11250/2649678 (accessed on 25 March 2021).

49. PSA. Barrier Memorandum 2017. In Principles for Barrier Management in the Petroleum Industry; Petroleum Safety Authority Norway: Stavanger, Norway, 2017; Available online: https:/ / www.ptil.no/contentassets/43fc402b97e64a7cbabdf91c64b349cb/ barriers-memorandum-2017-eng.pdf (accessed on 25 March 2021).

50. Internal Control Regulations. Forskrift om Systematisk Helse-, Miljø- og Sikkerhetsarbeid i Virksomheter (Internkontrollforskriten) (FOR-1996-12-06-1127). Ministry of Labour and Social Affairs, Oslo, Norway. 1996. Available online: https://lovdata.no/ dokument/SF / forskrift/1996-12-06-1127 (accessed on 24 March 2021).

51. Construction Client Regulations. Forskrift om Sikkerhet, Helse og Arbeidsmiljø på Bygge- Eller Anleggsplasser (Byggherreforskriften) (FOR-2009-08-03-1028). Ministry of Labour and Social Affairs, Oslo, Norway. 2009. Available online: https://lovdata.no/dokument/ SF/ forskrift/2009-08-03-1028 (accessed on 24 March 2021).

52. PSA. What Is Tripartite Collaboration? Available online: https://www.ptil.no/en/tripartite-cooperation/responsibility/ tripartite-collaboration-explained/ (accessed on 30 March 2021).

53. NOROG. Mandate for the Norwegian Oil and Gas Association Network for Safety and Emergency Response Training. Available online: https: / /www.norskoljeoggass.no/en/operations/mandate (accessed on 30 March 2021).

54. SfS. Working Together for Safety. Available online: http:/ / www.samarbeidforsikkerhet.no (accessed on 25 March 2021).

55. SfSBA. Fra Charter til SFS BA [From Chater to SFS BA]. Available online: https://sfsba.no/om-oss/fra-charter-til-sfs-ba/ (accessed on 22 May 2021).

56. Engen, O.A. Emergent Risk and New Technologies. In Risk Governance of Offshore Oil and Gas Operations; Lindøe, P.H., Baram, M., Renn, O., Eds.; Cambridge University Press: Cambridge, UK, 2015; pp. 340-359.

57. SSB. Statistics from STATBANK-09170: Production Account and Income Generation, by Industry 1970-2020. Available online: https:/ / www.ssb.no/en/statbank/table/09170 (accessed on 15 May 2021).

58. PSA. Risikonivå i Petroleumsvirksomheten. Hovedrapport, Utviklingstrekk 2015, Norsk Sokkel [Risk Level in the Petroleum Activities. Main Report, Development Trends 2015, Norwegian Continental Shelf]; Petroleum Safety Authority Norway: Stavanger, Norway, 2016; Available online: https://www.ptil.no/fagstoff/rnnp/rnnp-2019/eldre-rapporter/rnnp-2015/hovedrapport/ (accessed on 24 March 2021).

59. Bygballe, L.E.; Grimsby, G.; Engebretsen, B.E.; Reve, T. En Verdiskapende Bygg-, Anlegg- og Eiendomsnæring (BAE): Oppdatering 2019 [A Value Creating Construction Industry]; Centre for Construction Industry, Department of Strategy and Entrepreneurship, BI Norwegian Business School: Oslo, Norway, 2019; Available online: https:/ /biopen.bi.no/bi-xmlui/handle/11250/2629396 (accessed on 30 March 2021).

60. Andersen, R.K.; Jordfald, B. Arbeidstakere i Byggenæringen i 2008 og 2014 [Employees in the Construction Industry in 2008 and 2014]; Fafo: Oslo, Norway, 2016; Available online: https: / fafo.no/en/publications / fafo-reports/item/arbeidstakere-i-byggenaeringeni-2008-og-2014 (accessed on 25 March 2021).

61. Skullerud, H.F. SSB Analyse 2019/31: Petroleumsnæringens Økonomiske Utvikling og Framtidsutsikter. Ettermiddagsbyger Eller Væromslag for Norsk Sokkel? [Statistics Norway Analysis 2019/31: The Petroleum Industry's Economic Development and Future Prospects. Afternoon Showers or Weather Change for the Norwegian Shelf?]. Available online: https://www.ssb.no/energi-ogindustri/artikler-og-publikasjoner/ettermiddagsbyger-eller-vaeromslag-for-norsk-sokkel (accessed on 30 March 2021).

62. Ministry of Labour and Social Affairs. Meld. St. 12 (2017-2018) Report to the Storting (White Paper)—Health, Safety and Environment in the Petroleum Industry. 2018. Available online: https://www.regjeringen.no/contentassets/258cadcb3cca4e3c8 7c858fd787e0f75/en-gb/pdfs/stm201720180012000engpdfs.pdf (accessed on 25 March 2021).

63. Kongsvik, T.; Albrechtsen, E.; Antonsen, S.; Herrera, I.A.; Hovden, J.; Schiefloe, P.M. Sikkerhet i Arbeidslivet [Safety in Working Life]; Fagbokforlaget: Bergen, Norway, 2018.

64. Office of the Auditor General. The Office of the Auditor General's Investigation of the PSA's Follow-Up of Health, Safety, and Environment in the Petroleum Industry. 2019. Available online: https://www.riksrevisjonen.no/globalassets/reports/en-2018-2 019/psafollowup.pdf (accessed on 30 March 2021).

65. Renn, O. Risk Governance: Coping with Uncertainty in a Complex World; Earthscan: London, UK, 2008.

66. Bryman, A. Social Research Methods, 4th ed.; Oxford University Press: Oxford, UK, 2012.

67. Patton, M.Q. Qualitative Research \& Evaluation Methods, 3rd ed.; Sage Publications: Thousand Oaks, CA, USA, 2002.

68. Strauss, A.; Corbin, J.M. Basics of Qualitative Research: Grounded Theory Procedures and Techniques; Sage Publications, Inc.: Newbury Park, CA, USA, 1990.

69. Haukelid, K. Theories of (safety) culture revisited-An anthropological approach. Saf. Sci. 2008, 46, 413-426. [CrossRef]

70. Hudson, P. Applying the lessons of high risk industries to health care. BMJ Qual. Saf. 2003, 12 (Suppl. 1), i7-i12. [CrossRef] [PubMed]

71. Drottz-Sjöberg, B.-M.; Sjöberg, L. The perception of risks of technology. In Risks in Technological Systems; Grimvall, G., Holmgren, Å., Jacobsson, P., Thedéen, T., Eds.; Springer: New York, NY, USA, 2009; pp. 255-271. 
72. Antonsen, S.; Skarholt, K.; Ringstad, A.J. The role of standardization in safety management—A case study of a major oil \& gas company. Saf. Sci. 2012, 50, 2001-2009. [CrossRef]

73. Milch, V.; Laumann, K. The influence of interorganizational factors on offshore incidents in the Norwegian petroleum industry: Challenges and future directions. Reliab. Eng. Syst. Saf. 2019, 181, 84-96. [CrossRef]

74. Quinlan, M.; Mayhew, C.; Bohle, P. The Global Expansion of Precarious Employment, Work Disorganization, and Consequences for Occupational Health: A Review of Recent Research. Int. J. Health Serv. 2001, 31, 335-414. [CrossRef] [PubMed]

75. Mohamed, S.; Chinda, T. System dynamics modelling of construction safety culture. Eng. Constr. Archit. Manag. 2011, 18, 266-281. [CrossRef]

76. Carrillo, P. Managing knowledge: Lessons from the oil and gas sector. Constr. Manag. Econ. 2004, 22, 631-642. [CrossRef]

77. Di Maggio, P.J.; Powell, W.W. The iron cage revisited: Institutional isomorphism and collective rationality. Am. Sociol. Rev. 1983, 48, 147-160. [CrossRef]

78. Albrechtsen, E.; Solberg, I.; Svensli, E. The application and benefits of job safety analysis. Saf. Sci. 2019, 113, 425-437. [CrossRef] 